\title{
ESENSI AL-MASHLAHAH AL-MURSALAH DALAM TEORI ISTINBAT HUKUM IMAM SYAFI'I
}

\author{
Noorwahidah \\ Fakultas Syariah IAIN Antasari Banjarmasin, Jl. Jenderal Ahmad Yani Km 4,5 Banjarmasin \\ e-mail:wahidah.noor@gmail.com
}

\begin{abstract}
Imam Muhammad bin Idris asy-Syafi'I does not use al-mashlahah al-mursalah as one of the methodologies in making his law. He personally believes that the problem of laws, which do not have nas explicitly in the Holy Al-Qur'an or badist, can be solved through ijtihad. The ijtihad is qiyas. Imam Muhammad bin Idris asy-Syafi'I divides qiyas into three kinds: qiyas aqwa, qiyas musawi, and qiyas adb'af. His concept of qiyas is elastic and flexible enough to be able to solve the problem of laws in every place and time. In qiyas, there is the essence of al-maslahab al-mursalah.
\end{abstract}

Abstrak: Imam Muhammad bin Idris asy-Syafi $i$ tidak menjadikan al-mashlahah al-mursalah sebagai salah satu metode istinbat hukumnya. Ia berkeyakinan, semua persoalan hukum yang tidak ada nas secara eksplisit di dalam al-Quran atau hadis dapat diselesaikan melalui ijtihad. Ijtihad tersebut adalah qiyas. Ia membagi qiyas kepada tiga macam: qiyas aqwa, qiyas musawi, dan qiyas adb af. Qiyas yang dikonsepsikannya memiliki daya elastisitas dan fleksibelitas yang tinggi sehingga dapat menyelesaikan berbagai persoalan hukum di segala tempat dan zaman. Di dalam qiyas juga terkandung esensi almaslahah al-mursalah.

Kata kunci: Maslahat, al-mashlahah al-mursalah, maqashid asy-syari ah, qiyas, Imam Syafi i

\section{Pendahuluan}

Salah satu masalah yang menjadi tema utama dalam kajian Ushul Fiqih adalah kemaslahatan umat manusia yang terkandung di dalam syariat yang diturunkan Allah Swt. kepada mereka. Berangkat dari kajian tersebut, lahirlah teori istinbat hukum yang mengacu kepada konsep kemaslahatan, di antaranya ialah al-mashlabah almursalah.

Di dalam Al-Quran dan hadis, baik secara eksplisit maupun implisit, banyak sekali postulat yang menjelaskan bahwa tujuan Allah Swt. menurunkan hukum syara' ke muka bumi adalah untuk mewujudkan kemaslahatan hidup bagi umat manusia dan menghindarkan mereka dari mafsadat atau kerusakan. Kemaslahatan dimaksud bukan saja kemaslahatan duniawi, tetapi juga kemaslahatan ukhrawi atau dalam istilah Abu Ishaq asy-Syathibi: "li mashalih al'ibad fi al'ajil wa al-ajil" (untuk kemaslahatan hamba Allah di dunia dan di akhirat). ${ }^{1}$ Dengan demikian, apabila umat manusia tunduk dan melaksanakan syariat Allah Swt. dengan baik dan benar sesuai dengan petunjuk yang diberikan oleh Allah dan Rasulullah Saw. maka kebahagiaan dan ke-

1 Abu Ishaq asy-Syathibi, Al-Muwafaqat fi Ushul asySyari'ah, tahqiq Syekh Abdullah Darraz, Juz II, Dar al-Kutub al-'Ilmiyah, Beirut, cet. pertama, 1991, hlm. 4. selamatan hidup di dunia dan di akhirat akan terwujud.

Meskipun kemaslahatan manusia merupakan tujuan utama diturunkannya hukum syara' ke muka bumi, namun tidak semua maslahat yang ada di tengah-tengah umat manusia sejalan dengan hukum syariat dan tidak semua maslahat yang berkembang di masyarakat mempunyai dasar hukum yang akurat. Karena itu, para ulama membagi mashlahat kepada beberapa bentuk. Hujjatul Islam, Imam Al-Ghazali, misalnya, membagi maslahat kepada empat macam:

1. Maslahat yang diakui nau'-nya oleh Syari' karena ada kesamaan nau' tersebut dengan ashal dan furu'.

2. Maslahat yang diakui jins-nya oleh Syari' karena ada kesamaan jins tersebut dengan ashl dan furu'. Maslahat ini sering disebut pula almashlahah al- mula'imah li jins tasharrufat asysyar'.

3. Maslahat yang bertentangan dengan syara' yang disebut dengan istilah al-mashlabah albathilah atau al-mashlahah al-mulghah.

4. Maslahat yang tidak disebut-sebut oleh syara', tidak ada nas yang mendukungnya, dan tidak 
ada pula nas yang menentangnya. Maslahat semacam ini disebut al-mashlahah al-gharibah. ${ }^{2}$

Dari keempat pembagian di atas, Imam alGhazali memasukan al-mashlabah al-mursalab ke dalam pembagian yang kedua, yaitu maslahat yang diakui jins-nya oleh syara' dan ini dapat diterimanya sebagai hujjah atau dalil hukum. Sedangkan al-mashlabah al-gharibah dan almashlahah al-bathilah atau al-mashlahah al-mulghah ditolaknya secara mutlak. ${ }^{3}$

Berbeda dengan Imam Ghazali, Dr. Mushthafa Sa'id al-Khin membagi maslahat kepada tiga:

1. Maslahat yang diakui oleh asy-Syari', yaitu mashlahah dharuriyah, mashlabah bajizyah, dan mashlabah tabsiniyah.

2. Maslahat yang tidak diakui oleh asy-Syari', yaitu maslahat yang disebut dengan almashlahah al-mulghah.

3. Maslahat yang tidak memiliki dasar nas untuk diakui atau tidak diakui, yang dikenal dengan istilah al-mashlahah al-mursalah. ${ }^{4}$

Senada dengan Mushthafa Sa'id al-Khan, Dr.

Abdul Karim Zaidan juga membagi maslahat kepada tiga macam:

1. Maslahat yang ditetapkan oleh asy-Syari untuk diwujudkan. Maslahat ini disebut almashlahah al-mu tabarab;

2. Maslahat yang ditetapkan oleh asy-Syari untuk ditinggalkan atau diabaikan. Maslahat ini disebut al-mashlabah al-Mulghab;

3. Maslahat yang tidak ditetapkan oleh asySyari untuk mewujudkan atau mengabaikannya. Maslahat ini disebut almaslahah al-mursalah. ${ }^{5}$

Dari keterangan di atas tampak ada perbedaan pengertian tentang al-mashlahah al-mursalah antara Imam Ghazali dan Mushthafa Sa'id al-Khan. Menurut Imam Ghazali, al-mashlabah al-mursalah adalah maslahat yang jinsnya diakui oleh syara'. Ini berarti ada nas yang bisa dijadikan rujukan secara implisit. Sedangkan menurut Mushthafa Sa'id al-Khan, al-mashlabah al-mursalab adalah maslahat yang tidak memiliki dasar nas untuk

2 Abu Hamid Muhammad bin Muhammad al-Ghazali, Al-Mustashfa min 'Ilm al-Ushul, Juz II, Dar al-Fikr, Kairo, 1937, hlm. 306.

3 Ibid., hlm. 19.

4 Mushthafa Sa'id al-Khan, Atsar al-Ikhtilaf fi al-Qawa'id al-Ushuliyyah fi al-Ikhtilaf al-Fuqaha; Mu'assasah arRisalah, Beirut, 1972, hlm. 552.

5 Dr. 'Abd al-Karim Zaidan, Al-Wajiz fi Ushul al-Fiqh, Muassasah ar-Risalah, Beirut, cet. ke-7, 1998, hlm. 236. diakui atau tidak diakui. Bagi Imam Ghazali, maslahat yang tidak memiliki dasar nas untuk diakui atau tidak diakui itu disebutnya almashlahah al-gharibah.

Di samping perbedaan mengenai pengertian al-mashlahah al-mursalah para ulama juga berbeda pendapat tentang kehujjahannya sebagai dalil syara'. Sebagian mereka berpendapat, al-mashlahah al-mursalah dapat dijadikan dalil hukum, sementara sebagian lain berpendapat tidak.

Imam Muhammad bin Idris asy-Syafi'i (selanjutnyar disebut Imam Syafi'i), seorang tokoh besar ilmu Ushul Fikih dan salah seorang imam mazhab terkenal di dunia Islam dengan jumlah pengikut yang sangat banyak, sama sekali tidak menyinggung masalah al-mashlahah almursalah di dalam teori istinbat hukumnya sehingga tidak jelas apakah ia menerima atau menolaknya.

Untuk memecahkan berbagai problema yang tidak ada ketentuan hukumnya secara eksplisit di dalam nas, Imam Syafi'i mengajukan konsep qiyas sebagai alternatif pemecahan. Dengan qiyas tersebut, menurutnya, berbagai masalah hukum yang terjadi di masyarakat akan dapat diselesaikan. Qiyas bagi Imam Syafi i tidak lain kecuali ijtihad.

Disebabkan karena al-mashlahah al-mursalah merupakan salah satu masalah hukum yang sering dijumpai di tengah-tengah kehidupan umat manusia, sementara Imam Syafi'i tidak menegaskan penerimaan atau penolakannya maka timbul pertanyaan, apakah masalah ini termasuk di dalam qiyas yang dikonsepsikannya atau tidak? Jika termasuk, bagaimana wujudnya? Jika tidak, apakah berarti ia menolak al-mashlahah al-mursalah sebagaimana penolakannya terhadap istibsan?

Ringkasan hasil penelitian penulis berikut ini akan memberikan jawaban atas beberapa pertanyaan tersebut.

\section{Pengertian Al-mashlahah al-mursalah}

Al-mashlahah al-mursalah menurut Muhammad Abu Zahrah ialah:

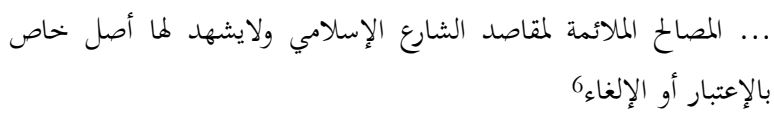

...maslahat-maslahat yang bersesuaian dengan tujuantujuan syariat Islam dan tidak ditopang oleh dalil yang

6 Muhammad Abu Zahrah, Ushul al-Fiqih, Dar al-Fikr al-`Arabi, Kairo, t.th., hlm 249. 
khusus, baik yang bersifat melegitimasi atan yang membatalkan maslahat tersebut.

Menurut para ahli Ushul Fiqih, al-mashlabah almursalab ialah:

المصلحة التى لم يشرع الشارع حكما لتحقيقها ولم يدل دليل شرعي على

$$
\text { اعتبارها أو الغائها }
$$

Suatu kemaslahatan yang tidak ditetapkan oleh asySyari' (Pembuat Syariat) bukum untuk melegitimasinya dan tidak ada pula dalil syara' yang memerintabkan untuk memperbatikan atau mengabaikannya.

Berbeda dengan kedua rumusan di atas, Dr. Husain Hamid Hassan mendefinisikan almashlahah al-mursalah sebagai berikut:

... إن المصلحة المرسلة هي المصلحة التى تحت جنس اعتبره الشارع فن

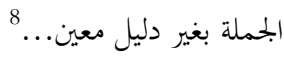

Sesunggubnya al-mashlahah al-mursalab ialah maslabat yang termasuk di dalam jenis yang diungkapkan asySyari' (Pembuat Syariat) secara global tanpa adanya dalil yang jelas ...

Maslahat sebagaimana disebutkan di atas disebut oleh Dr. Husain Hamid Hassan dengan istilah al-mashlahah al-mula'imah li jins tasharrufat asy-Syari' yang mengandung arti:

$$
\text { .... }
$$

... Penetapan bukum yang diambil dari makna implisit (tersirat) dari nas dan ijma ....

Dengan kalimat sederhana tetapi mudah difahami, Prof. Dr. Mukhtar Yahya dan Prof Drs. Fatchurrahman memberikan definisi almashlabah al-mursalah sebagai "suatu kemaslahatan yang tidak ditetapkan oleh syara` suatu hukum untuk mewujudkannya dan tidak pula terdapat suatu dalil syara' yang memerintahkan untuk memperhatikannya atau mengabaikannya." 10

Dari beberapa definisi di atas terlihat bahwa unsur-unsur utama di dalam al-mashlahah almursalab adalah:

1. Adanya kemaslahatan yang terkandung di dalam suatu peristiwa atau kasus yang akan

7 'Abd al-Wahhab Khallaf, 'Ilm Ushul al-Figh, Dar alQalam, Kuwait, Cet. ke-12, 1978, hlm 84.

8 Dr.Husain Hamid Hassan, Ną̧hariyyah al-Mashlabah fi al-Figh al-Islamiy, Dar an-Nahdhah al-'Arabiyyah, Kairo, 1971, hlm 322.

9 Ibid.

10 Prof. Dr. Mukhtar Yahya dan Prof Drs. Fatchurrahman, Dasar-Dasar Pembinaan Hukum Fiqh Islami, PT Al-Ma rif, Bandung, 1986, hlm. 105. ditentukan hukumnya melalui al-mashlahah al-mursalab.

2. Maslahat yang terkandung di dalam peristiwa atau kasus tersebut tidak bertentangan dengan maqashid asy-syariah (tujuan syariat).

3. Tidak ada nas yang jelas dan tegas (konkret) yang memotivasi untuk mewujudkan kemaslahatan tersebut dan tidak ada pula nas memerintahkan mengabaikannya.

Dengan demikian, inti pokok dari al-mashlabah al-mursalah adalah ketiadaan nas mengenai suatu peristiwa yang di dalamnya terdapat kemaslahatan yang tidak bertentangan dengan tujuan syariat. Dengan kata lain, nas tidak membicarakan kemaslahatan tersebut, baik dalam bentuk menetapkan hukumnya, memerintahkan mewujudkannya, maupun melarang memperhatikannya.

Beberapa contoh yang termasuk dalam kategori al-mashlabah al-mursalah adalah "mengadakan lembaga pemasyarakatan (penjara), mencetak mata uang sebagai alat pertukaran resmi dari suatu negara dan membiarkan tanahtanah agraria yang terdapat di daerah-daerah yang telah dikuasai oleh kaum muslimin tetap berada di tangan pemiliknya semula dengan ketentuan mereka dikenakan kewajiban membayar pajak atau kewajiban-kewajiban lainnya".11

\section{Kehujjahan Al-mashlahah al-mursalah}

Karena tidak ada nas yang memerintahkan atau melarang perwujudan kemaslahatan yang terkandung di dalam al-mashlahab al-mursalab maka para ulama berbeda pendapat mengenai kebolehan penggunaannya sebagai dalil syara'. Sebagian mereka menerima dan sebagian lain menolaknya.

Jumhur ulama menerimanya sebagai dalil syara' karena beberapa alasan:

1. Kemaslahatan manusia itu terus berkembang dan bertambah mengikuti perkembangan kebutuhan manusia. Seandainya kemaslahatan-kemaslahatan yang sedang berkembang itu tidak diperhatikan, sedang yang diperhatikan hanyalah kemaslahatan yang ada nasnya saja, niscaya banyak kemaslahatan manusia yang terdapat di beberapa daerah dan pada masa yang berbeda akan mengalami kekosongan hukum dan syari'at sendiri tidak dapat mengikuti perkembangan kemaslahatan

11 Ibid., hlm. 105-106. 
manusia. Padahal tujuan syari'at adalah untuk mewujudkan kemaslahatan manusia di setiap tempat dan masa.

2. Menurut penyelidikan, hukum-hukum, putusan-putusan, dan peraturan-peraturan yang diproduksi oleh para sahabat, tabi'in dan imam-imam mujtahidin adalah untuk mewujudkan kemaslahatan bersama. ${ }^{12}$

Alasan jumhur ulama di atas sejalan dengan alasan Imam Malik bin Anas, yang dikenal sebagai tokoh dan pelopor al-mashlahah almursalah. Menurut Imam Malik, al-mashlahah almursalah dapat dijadikan sebagai dalil syara' dengan alasan sebagai berikut:

1. Para sahabat banyak yang menggunakan almashlahah al-mursalah di dalam mengambil kebijaksanaan dan istinbat hukum, seperti sahabat yang mengumpulkan Al-Quran, alKhulafa al-Rasyidun yang menetapkan keharusan menanggung ganti rugi kepada para tukang, Umar bin Khaththab yang memerintahkan para pejabat agar memisahkan harta kekayaan pribadinya dari kekayaan yang diperoleh karena jabatannya, Umar bin Khaththab yang sengaja menumpahkan susu yang dicampur dengan air guna memberi pelajaran kepada orang-orang yang mencampur susu dengan air, dan para sahabat yang menetapkan hukuman mati terhadap semua anggota kelompok atau jamaah yang melakukan pembunuhan terhadap satu orang jika mereka melakukan pembunuhan itu secara bersama-sama.

2. Perwujudan kemaslahatan itu sesuai dengan tujuan syariat. Mengambil maslahat berarti sama dengan merealisasikan tujuan syariat. Mengesampingkan maslahat berarti mengesampingkan tujuan syariat.

3. Seandainya maslahat tidak diambil pada setiap kasus yang jelas mengandung maslahat selama berada di dalam konteks maslahat syariyyah maka orang-orang mukallaf akan mengalami kesulitan dan kesempitan, padahal Allah Swt. tidak menghendaki adanya kesulitan itu sebagaimana dikemukakan Allah di dalam surat Al-Baqarah ayat 185 dan Al-Hajj ayat 78.13 berbunyi:

Surat Al-Baqarah ayat 185 dimaksud

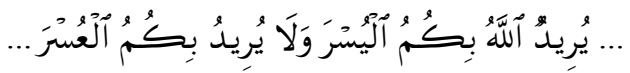

12 Ibid., hlm 107.

13 Lihat Muhammad Abu Zahrah, op. cit., hlm 281-282.
... Allah menghendaki kemudahan bagimu, dan tidak menghendaki kesukaran bagimu.... ${ }^{14}$

Dan surat al-Hajj ayat 78 berbunyi:

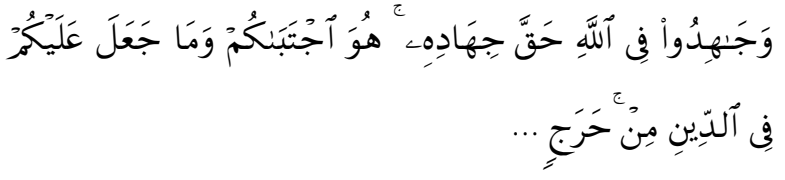

Dan berjihadlah kamu pada jalan Allah dengan jihad yang sebenar-benarnya. dia telab memilib kamu dan dia sekali-kali tidak menjadikan untuk kamu dalam agama suatu kesempitan... ${ }^{15}$

Meskipun Imam Malik merupakan tokoh dan pelopor al-mashlabah al-mursalab namun di dalam penerapannya, pendiri mazhab Maliki ini menetapkan syarat-syarat sebagai berikut:

1. Adanya persesuaian antara maslahat yang dipandang sebagai sumber dalil yang berdiri sendiri dengan tujuan-tujuan syariat.

2. Maslahat itu harus masuk akal dan mempunyai sifat-sifat yang sesuai dengan pemikiran yang rasional.

3. Penggunaan dalil maslahat ini adalah dalam rangka menghilangkan kesulitan yang mesti terjadi. Dengan kata lain, jika maslahat itu tidak diambil, manusia akan mengalami kesulitan. ${ }^{16}$

Para ulama yang tidak menerima al-mashlabah al-mursalah sebagai dalil syara' juga mengemukakan beberapa alasan:

1. Maslahat yang tidak didukung oleh dalil khusus akan mengarah kepada salah satu bentuk pelampiasan dari keinginan hawa nafsu yang cenderung mencari yang enakenak saja, padahal prinsip Islam tidak demikian.

2. Jika maslahat dapat diterima (mu'tabarah), ia termasuk ke dalam kategori qiyas dalam arti luas. Jika tidak mu'tabarah, ia tidak termasuk qiyas. Tidak dibenarkan anggapan yang menyatakan bahwa pada suatu masalah terdapat mashlahah mu'tabarah, sementara maslahat itu tidak termasuk di dalam nas atau qiyas.

14 Dewan Penterjemah, Al-Quran dan Terjemabnya, Mujamma` Khadim al-Haramain asy-Syarifain alMalik Fahd li Thiba`at al-Mushhaf asy-Syarif, Saudi Arabia, t.th., hlm. 45.

15 Ibid., hlm. 523.

16 Lihat Muhammad Abu Zahrah, op. cit., hlm. 279-280. 
3. Mengambil dalil maslahat tanpa berpegang kepada nas terkadang akan berakibat kepada suatu penyimpangan dari hukum syariat dan tindakan kelaliman terhadap rakyat dengan dalil maslahat, sebagaimana dilakukan oleh raja-raja yang lalim.

4. Jika maslahat dijadikan sebagai sumber hukum pokok yang berdiri sendiri, niscaya hal itu akan menimbulkan terjadinya perbedaan hukum akibat perbedaan negara, bahkan perbedaan pendapat perorangan di dalam suatu perkara. ${ }^{17}$

\section{Pandangan Imam Syafi'i Terhadap al- Mashlahah al-Mursalah}

Sebagaimana disebutkan terdahulu, Imam Syafi $i$ tidak menyinggung masalah al-mashlahah al-mursalah di dalam teori istinbat hukumnya sehingga tidak ada kejelasan apakah ia menerima atau menolaknya. Akan tetapi, satu prinsip yang dipegang oleh Imam Syafi'i ialah bahwa tidak ada satu masalah pun yang tidak dapat diselesaikan karena petunjuk di dalam kitab Allah Swt. sudah lengkap. ${ }^{18}$

Petunjuk itu ada dua macam, ada yang terungkap secara jelas (eksplisit), ada pula yang tersembunyi (implisit). Untuk dapat menemukan petunjuk yang tersembunyi (implisit) ini diperlukan ijtihad, dan bagi Imam Syafi'i ijtihad itu adalah qiyas. Dengan demikian, masalah-masalah yang tidak ada ketentuan hukumnya secara eksplisit di dalam nas dapat digali melalui qiyas dengan mencari makna-mana implisit yang terkandung di dalam nas itu.

Al-mashlahah al-mursalah adalah suatu maslahat yang tidak ada ketetapan hukumnya secara tegas di dalam nas; juga tidak ada perintah atau larangan untuk mewujudkannya. Imam Syafi'i sendiri tidak membicarakannya secara khusus. Karena itu, untuk mengetahui pandangan Imam Syafi'i terhadap masalah ini dapat dilihat dari konsep qiyas yang diajukannya.

Apabila diperhatikan konsep Imam Syafi'i tentang qiyas dan dihubungkan dengan masalah kemaslahatan umat manusia yang merupakan tujuan dari diturunkannya syariat ke muka bumi dapat disimpulkan hal-hal sebagai berikut:

1. Penetapan suatu hukum melalui qiyas pada hakekatnya adalah dalam rangka

17 Ibid., hlm. 282-283.

18 Muhammad bin Idris asy-Syafi'iy, Ar-Risalah, Tahqiq Ahmad Muhammad Syakir, Dar at-Turats, Kairo, cet. ke-2, 1979, hlm.20. mewujudkan maqashid asy-syariah, dan inti dari tujuan syariat ialah al-mashlabah.

2. Qiyas adalah pengambilan hukum dari nas secara maknawi (ma'qu), bukan secara literal (zabir). Karena itu, qiyas pada hakekatnya adalah pengamalan terhadap nas, dan setiap nas syariat mengandung maqashid asy-syari'ab (tujuan syariat).

3. Orang yang boleh melakukan qiyas adalah orang yang memenuhi syarat-syarat tertentu, termasuk mengetahui maqashid yang terkandung di dalam nas syariat. Karena itu, mujtahid yang menggunakan qiyas harus berpegang dan berorientasi kepada maqashid asy-syari'ah. Ia tidak boleh mengabaikan, apalagi bertentangan dengan maqashid asysyari'ah tersebut.

4. Pembagian qiyas kepada aqwa, musawi, dan adh'af menunjukkan bahwa orientasi qiyas yang dikonsepkan oleh Imam Syafi'i adalah kepada al-mashlabah; dalam arti, qiyas dilakukan dengan melihat dan memperhatikan secara serius kepada aspek al-mashlahah sehingga ada pengqiyasan karena tingkatnya lebih tinggi, ada pengqiyasan karena tingkatnya sama, ada pula pengqiyasan yang tingkatnya lebih rendah. Semua itu mempunyai keterkaitan dengan perwujudan maqashid asy-syari'ah.

Inti dari al-mashlabah al-mursalah adalah maslahat itu sendiri, hanya nas tidak menyinggung sama sekali kejadian atau peristiwa yang mengandung maslahat tersebut sehingga timbul berbagai pandangan ulama tentang kehujahan almaslahah al-mursalah.

Konsep qiyas yang dikemukakan Imam Syafi'i pada dasarnya bertolak dari upaya mewujudkan kemaslahatan umat manusia. Karena itu, orientasi penerapan qiyas pun ditujukan untuk kemaslahatan umat manusia tersebut. Dengan demikian, konsep ini sejalan dengan hakekat almashlahah al-mursalah.

Di dalam salah satu penjelasannya tentang qiyas Imam Syafi'i mengatakan:

حكم لله أو لرسوله وجدت عليه دلالة فيه أو فن غيره من أحكام الله كل

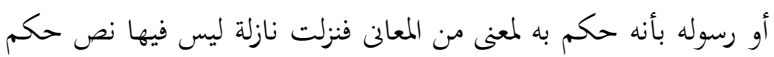

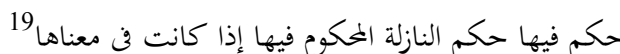

Setiap bukum yang ditetapkan Allah atau Rasul-Nya ada petunjuk di dalam ketetapan itu sendiri atau di dalam ketetapan yang lain dari bukum-bukum Allah

$19 \quad$ Ibid., hlm. 512 
atau Rasul-Nya babwa hal tersebut ditetapkan karena satu dari beberapa makna. Suatu kasus yang terjadi yang tidak ada ketentuan bukumnya di dalam nas, ditetapkan bukumnya sama dengan bukum peristiwa yang sudah ada ketentuannya di dalam nas, apabila ada kesamaan maknanya.

Dari keterangan Imam Syafi'i di atas dapat difahami bahwa qiyas yang dimaksudkannya adalah mengambil salah satu makna dari beberapa makna yang ada di dalam nas untuk diterapkan di dalam suatu peristiwa yang tidak disinggung oleh nas.

Imam Syafi'i tidak mempersoalkan apakah makna tersebut 'ain al-ma 'na ataukah jins al-ma 'na. Hal terpenting adalah bahwa di dalam peristiwa yang akan ditentukan hukumnya terdapat makna yang sama dengan makna yang terkandung di dalam peristiwa yang sudah ada ketentuan hukumnya di dalam nas. Karena itu, sekalipun makna yang terkandung di dalam suatu peristiwa yang akan ditentukan hukumnya itu hanya ada persamaan jins ma'na-nya, bukan persamaan 'ain ma'na-nya, qiyas bisa dilakukan.

Adapun yang dimaksud dengan "makna" di dalam konsep qiyas Imam Syafi i adalah illat yang merupakan bagian dan unsur penting di dalam qiyas. Tanpa ada illat, qiyas tidak bisa dilakukan. Bahkan, lebih jauh lagi, di dalam teori Ushul Fiqh, illat memegang peranan kunci untuk menetapkan suatu hukum, sehingga dikenal sebuah qaidah:

$$
\text { الحكم يدور مع العلة وجودا وعدما }
$$

Hukum itu berputar bersama illatnya dalam mewujudkan dan meniadakan bukum. ${ }^{20}$

Menurut Hujjatul Islam, Imam Ghazali, salah seorang tokoh Syafi iyah, "Yang dimaksud dengan illat ialah sifat yang memberi bekas (berpengaruh) terhadap hukum dengan sebab yang ditetapkan Allah."21 Pengikut Imam Syafi $i$ yang lain, Fakhruddin ar-Razi, memberikan definisi yang sedikit berbeda, tetapi memiliki esensi yang sama. Menurutnya, “illat ialah sifat

20 Prof.Dr.H.Mukhtar Yahya dan Prof. Drs. Fatchurrahman, op. cit., hlm. 550. lihat juga Drs. H. Mukhlis Usman, MA, Kaidah-Kaidah Ushuliyah dan Fiqhiyah, PT RajaGrafindo Persada, Jakarta, cet. II, 1997, hlm 192.

21 Abu Hamid Muhammad bin Muhammad Al-Gazali, Syifa' al-Ghalil fì Bayan asy-syabh al-Mubil wa Masalik atTa Yil, Maktabah Al-Azhar, Kairo, t.th., hlm. 20. yang mengenalkan (mengidentifikasikan) bagi suatu hukum." 22

Imam Syafi i sendiri tidak memberikan definisi khusus mengenai illat, bahkan ia tidak menyebutnya dengan istilah illat. Sebagaimana digambarkan di atas, Imam Syafi i menyebutnya dengan istilah "makna", tetapi yang dimaksudkannya sama dengan istilah "illat" yang dipergunakan oleh para ahli Ushul Fiqih yang lain.

Pada bagian lain Imam Syafi i mengatakan: أن يكون الله أو رسوله حرم الشيئ منصوصا أو أحله لمعنى فإذا وجدنا ما

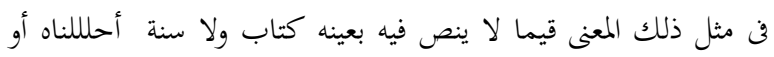
حرمناه لأنه في معنى الحلال أو الحرام 23 ... bahwa Allab dan Rasul-Nya mengharamkan sesuatu berdasar nas yang jelas (manshush) atau menghalalkan sesuatu itu karena makna yang tersirat (illat tertentu). Apabila kita menemukan sesuatu yang serupa atau sama dengan makna tersebut di dalam peristiwa yang tidak ada nas yang jelas di dalam AlQuran atau sunnah maka kita tetapkan bukum halal atau haram terhadap peristiwa itu karena persamaan makna halal atau haramnya.

Ungkapan ini memberi pengertian bahwa makna ('illat) bagi Imam Syafi i adalah "sesuatu yang memberikan ciri atau mengidentifikasi (mu arrif)" terhadap adanya hukum bagi far' (cabang) atau "memberikan pengaruh (mu atstsir)" bagi keberadaan hukum pada far' tersebut. Pengertian ini dapat difahami dari ungkapannya "Apabila kita menemukan sesuatu yang sama dengan makna yang jelas di dalam AlQuran atau Sunnah maka kita tetapkan hukum halal atau haram terhadap peristiwa itu karena persamaan makna halal atau haramnya".

Dengan demikian, pengertian illat yang dikemukakan oleh Imam Gazali dan Fakhruddin ar-Razi di atas sejalan dengan apa yang dimaksud oleh Imam Syafi i mengenai "makna" ( illat).

Dalam hubungan dengan masalah makna (illat) ini, Imam Syafi i tidak menegaskan apakah illat itu harus bersifat zabir (jelas dapat diketahui dengan pancaindera) ataukah khafi (tersembunyi). Ia juga tidak menegaskan apakah illat yang dimaksudkannya harus bersifat mundhabit (dapat diidentifikasi) ataukah taqdiri (tidak dapat diidentifikasi). Namun, jika diperhatikan pemikiran Imam Syafi i sebagaimana yang tertuang di

22 Fakhruddin ar-Razi, Al-Mahshul fi 'Tlm Ushul al-Fiqh, Jilid II, Jami al-Imam Muhammad bin Sa`ud, Mekkah,1980, hlm 189.

23 Muhammad bin Idris asy-Syafi i, op. cit., hlm. 40. 
dalam karya besarnya, kitab Al-Umm, tampak bahwa ia lebih cenderung menggunakan illat yang bersifat zabir dan mundhabit, daripada yang bersifat khafi dan taqdiri.

Ketika berbicara tentang shalat qashar di waktu melakukan perjalanan (safar), misalnya, ia mengatakan,"... mengqashar shalat di dalam keadaan takut dan sedang melakukan perjalanan (safar) ditetapkan berdasarkan Al-Kitab (Al-Quran), kemudian (diperkuat) dengan sunnah (hadis). Sedangkan mengqashar shalat di dalam safar tanpa rasa ketakutan adalah sunnat. Al-Quran menunjukkan bahwa kebolehan qashar di saat melakukan safar tanpa rasa ketakutan merupakan rukhshah (keringanan) dari Allah 'Azza wa Jalla", bukan merupakan suatu kewajiban, seperti safar dalam keadaan ketakutan....".24 Selanjutnya ia mengatakan, "Maka yang menjadi pilihan dan yang saya sukai untuk dilakukan selama safar ialah mengqashar shalat, baik dalam keadaan ketakutan maupun tidak."25

Pernyataan Imam Syafi $i$ yang terakhir ini menunjukkan bahwa illat pelaksanaan shalat qashar adalah "safar", bukan al-khauf (rasa takut). Baginya, ada atau tidak ada rasa takut ketika melakukan safar bukanlah masalah, shalat qashar tetap dilaksanakan. Jadi, bukan karena ada "rasa takut" baru shalat tersebut dikerjakan, tetapi asal ada aktivitas "safar" yang memenuhi syarat, shalat qashar sudah bisa dilakukan. Dengan demikian, illat kebolehan qashar, menurut Imam Syafi i adalah aktivitas safar sendiri. Ini berarti illat tersebut bersifat zahir karena aktivitas safar dapat dilihat, didengar, dan diketahui dengan jelas melalui pancaindera. illat ini juga bersifat mundhabit karena dapat diidentifikasi, misalnya, jaraknya bisa diukur, berapa kilometer jauhnya perjalanan itu.

Contoh lain dapat dilihat dari pendapat Imam Syafi $i$ tentang 'iddah wanita yang dicerai atau ditinggal mati oleh suaminya. Ia mengatakan, "Apabila seorang wanita mengetahui dengan yakin bahwa suaminya telah meninggal dunia atau telah menceraikannya dengan bukti yang bisa dijadikannya pegangan yang menunjukkan kematian suaminya atau penjatuhan talak, atau dengan dasar pengetahuan yang benar, maka ia wajib ber-'iddah mulai dari hari jatuhnya talak atau hari terjadinya kematian itu. ${ }^{26}$

\footnotetext{
24 Muhammad bin Idris asy-Syafi i, Al-Umm, Juz I, Dar al-Fikr, Beirut, cet. II, 1983, hlm. 208.

25 Ibid.

26 Ibid., Juz III, hlm. 231.
}

Ungkapan di atas menunjukkan bahwa illat kewajiban ber'iddah bagi wanita yang ditinggal mati atau dicerai oleh suaminya, menurut Imam Syafi $i$, adalah kematian atau perceraian itu sendiri, bukan "duka cita" (dalam kasus kematian), bukan pula bara'ab ar-rabim (kebersihan rahim dari bibit suami) (dalam kasus perceraian). Ini berarti illat yang dipakai oleh Imam Syafi $i$ adalah 'illat yang bersifat zabir dan mundhabit karena "kematian" dan "penjatuhan talak" dapat dilihat, didengar, diketahui oleh pancaindera, dan dapat diidentifikasi.

Andaikata yang menjadi illat-nya adalah "duka cita" atau bara ah ar-rabim, maka keduanya termasuk illat yang khafi dan taqdiri. Dalam hal ini, Imam Syafi $i$ ternyata tidak menggunakannya.

Illat tidaklah sama dengan maqashid asysyariah. Kalau illat merupakan suatu sifat yang memberikan pengaruh terhadap keberadaan suatu hukum, atau dengan bahasa yang lebih sederhana, illat adalah alasan mengapa ketentuan hukum itu demikian, maka maqashid asy-syariah adalah tujuan yang ingin dicapai oleh hukum itu sendiri. Maqashid asy-syariah secara umum meliputi tiga hal pokok:

Pertama, memelihara hal-hal yang bersifat dharuri atau disebut juga al-umur adh-dharuriyah, yaitu sesuatu yang harus ada di dalam kehidupan umat manusia agar manusia tetap eksis dan kehidupan mereka berjalan baik. Komponen yang termasuk di dalam perkara dharuri ini ada lima, yaitu agama, jiwa, akal, keturunan, dan harta benda. Dengan demikian, syariat diturunkan oleh Allah Swt. untuk memelihara kelima komponen dharuri tersebut.

Kedua, memelihara hal-hal yang bersifat hâji atau disebut juga al-umur al-bajiyah, yaitu sesuatu yang sangat diperlukan oleh umat manusia agar di dalam kehidupan ini mereka tidak mendapatkan kesulitan dan kesukaran.

Ketiga, memelihara hal-hal yang bersifat tabsini atau disebut juga al-umur al-tahsiniyah, yaitu segala sesuatu yang dapat mewujudkan sikap dan tindakan yang mulia dan agung (akblaq alkarimah). ${ }^{27}$ Dengan kata lain, al-umur at-tabsiniyah adalah sesuatu yang baik yang seharusnya dilakukan oleh manusia, termasuk di dalamnya menjauhi segala yang tidak baik, yang dapat mengurangi, apalagi merusakkan nilai-nilai kebaikan.

Illat juga tidak sama dengan maslahat karena maslahat pada hakikatnya adalah refleksi

27 Abu Ishaq asy-Syathibi, op.cit. hlm. 3-5. 
sekaligus inti dari maqashid asy-syariah. Imam Ghazali mengungkapkan apa yang dimaksud dengan masalahat, katanya:

"... tetapi yang kami maksudkan dengan maslahat ialah pemeliharaan terhadap tujuan syariat. Tujuan syariat yang berkaitan dengan manusia ada lima, yaitu terpeliharanya agama, jiwa, akal, keturunan, dan har ta benda mereka. Apa pun yang menjamin terpeliharanya lima hal ini adalah maslahat, sedangkan segala sesuatu yang tidak menjamin terpeliharanya lima hal tersebut adalah mafsadat (kerusakan), dan penolakan terhadapnya adalah maslahat.... "28

Sebagaimana illat, Imam Syafi i juga tidak memberikan penjelasan secara eksplisit tentang maqashid asy-syariah dan maslahat, tetapi tampaknya yang dimaksud oleh Imam Syafi` $i$ tidak berbeda dengan apa yang dikemukakan di atas bahwa maqashid asy-syari ab adalah tujuan diturunkannya syariat ke muka bumi dan maslahat adalah "pemeliharaan terhadap maqashid asy-syari ab" tersebut.

Sebagaimana dikemukakan terdahulu, di dalam pembahasan Ushul Fiqh, salah satu metode pembinaan hukum Islam yang dipergunakan oleh ulama untuk mewujudkan kemaslahatan umat manusia dan mewujudkan maqashid asy-syariah adalah al-mashlahah almursalah.

Dr. Husain Hamid Hassan menyebut almashlahah al-mursalah sebagai al-mashlahah almula'imah li jins tasharrufat al-tasyri'."29 Ini berarti bahwa al-mashlahah al-mursalah, sekalipun tidak disinggung oleh nas, namun ada persamaan maknanya dengan kasus yang disebut oleh nas. Persamaan itu terletak pada jins-nya, bukan pada 'ain-nya. Dengan demikian, dapat disimpulkan bahwa al-mashlahah al-mursalah termasuk di dalam qiyas yang dikonsepsikan oleh Imam Syafi'i.

Kesimpulan semacam inilah yang diambil oleh Dr. Husain Hamid Hassan sehingga dengan sangat tegas ia menyatakan:

$$
\text { فإن المصلحة المرسلة تكون داخلة تحت القياس في نظر الشافعى رضى الله }
$$

Sesunggubnya al-mashlahah al-mursalah itu masuk. ke dalam pengertian qiyas menurut pandangan Imam Syafi i r.a.

28 Abu Hamid Muhammad bin Muhammad al-Ghazali, op.cit., Juz I, hlm. 286.

29 Dr. Husain Hamid Hassan, op. cit., hlm. 322.

30 Ibid., hlm. 326.
Pada bagian lain ia mengatakan:

الدارس للإجتهاد فن كلام الشافعى يرى أنه شامل للمصلحة الملائمة

$$
\text { لمنس تصرفات الشرع } 31
$$

Orang yang mempelajari ijtibad menurut konsep Imam Syafi'i akan menemukan babwa ijtihad bagi Imam Syafi i mengandung al-mashlabah al-mula'imah li jins tasharrufat asy-syar $i . .$.

Yang dimaksud dengan ijtihad pada ungkapan di atas tidak lain kecuali qiyas sesuai dengan pernyataan Imam Syafi i sendiri bahwa ijtihad itu adalah qiyas.

Alasan yang dikemukakan Dr. Husain Hamid Hassan memasukkan al-mashlahah al-mursalah atau al-mashlahah al-mula'imah ke dalam qiyas Imam Syafi $i$ adalah adanya persamaan antara unsurunsur qiyas dengan unsur-unsur yang terdapat di dalam al-mashlabah al-mursalah.

Menurutnya, syarat qiyas ada tiga, yaitu (1) Adanya peristiwa yang tidak ada nas hukumnya yang jelas, (2) Adanya hukum yang dinaskan oleh asy-Syari yang mungkin dihubungkan dengan peristiwa itu melalui pengertian maknawi, (3) Peristiwa yang tidak ada nas hukumnya itu terkandung di dalam suatu kejadian yang manshush secara implisit. Ketiga syarat qiyas ini, menurutnya, sejalan dengan al-mashlahab almursalah atau al-mashlahah al-mula'imah, yaitu (1) Peristiwa yang ingin diketahui hukumnya melalui al-mashlabah adalah peristiwa yang tidak ada nasnya yang jelas, seperti jaminan atau ganti rugi para pekerja apabila merusak barang yang dikerjakan, (2) Ada hukum-hukum syariat ang dinaskan oleh asy-Syari atas suatu peristiwa yang maknanya dapat ditemukan oleh para mujtahid, (3) Peristiwa yang tidak ada nas secara jelas tersebut memiliki makna yang sama dengan makna yang terkandung di dalam peristiwa yang ada nasnya. ${ }^{32}$

Pada bagian lain Dr. Husain Hamid Hassan mengatakan:

إن المصلحة الملائمة لجنس تصرفات الشارع حجة في الإسدلال عند

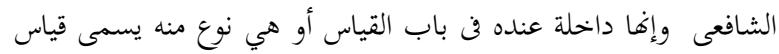
المعانى أو القواعد أو المصالح اذ قياس المصلحة على المصلحة أولى عنده من قياس الشئ على الشئ 33 Sesunggubnya al-mashlabah al-mula'imab li jins tasharrufat asy-Syari adalah bujjah di dalam istidlal Imam Syafi i. Ia termasuk di dalam Bab Qiyas atau

$31 \quad$ Ibid., hlm. 311.

$32 \quad$ Ibid., hlm. 324-325.

33 Ibid., hlm. 370. 
merupakan salah satu bentuk daripadanya yang dinamakan qiyas al-ma ani atau al-qawa id atau almashalih. Karena itu, qiyas al-mashlahah atas almashlahah menurut Imam Syafi i lebih utama daripada qiyas sesuatu atas sesuatu.

Dari uraian di atas terlihat bahwa masuknya al-mashlabah al-mursalah ke dalam qiyas Imam Syafi'i karena di dalam al-mashlahah tersebut masih terkandung makna implisit yang bisa dicarikan rujukannya kepada nas. Di samping itu, makna dan ruang lingkup qiyas yang dikonsepsikan oleh Imam Syafi'i sangat luas, elastis, dan fleksibel. Keluasan, elastisitas, dan fleksibelitas itu antara lain dapat dilihat pada pengertian dan bentuk-bentuk qiyas yang dikemukakannya.

Pengertian qiyas dimaksud tergambar dari ungkapan Imam Safi i:

$$
\text { ما عدا النص من الكتاب أو السنة فكان في معناه فهو قياس } 34
$$

Sesuatu yang tidak ada di dalam nas, baik. Al-Quran maupun hadis, tetapi memiliki kesamaan di dalam pengertian atau maknanya, maka itu adalah qiyas.

والقياس ما طلب بالدلائل على موافقة الخبر المتقدم من الكتاب أو السنة

$$
\text { لأغما علم الحق المفترض طلبه. } 35
$$

Qiyas adalah sesuatu yang didasarkan kepada dalil-dalil atas dasar kesesuaian informasi sebelumnya, baik informasi Al-Quran maupun as-sunnah, karena keduanya merupakan sumber kebenaran yang wajib dituntut.

كل ما نزل بمسلم ففيه حكم لازم أو على سبيل الحق فيه دلالة موجودة وعليه إذا كان بعينه حكم - -تباعه وإذا لم يكن فيه بعينه طلب الدلالة على سبيل الحق فيه بالإجتهاد. والإجتهاد القياس. 36

Segala sesuatu yang diturunkan Tuban kepada seorang muslim, di dalamnya terkandung bukum yang tetap, atau sesuatu yang diturunkan atas jalan yang benar, di dalamnya ada dalil yang eksis; dan wajib-apabila di dalamnya ada kejelasan bukum-mengikutinya. Tetapi, apabila tidak ada kejelasan bukum di dalamnya maka ditempuh dilalab melalui jalan yang bak, dengan melakukan ijtihad dan ijtihad itu adalah qiyas.

34 Muhammad bin Idris Asy-Syafi'iy, Ar-Risalah, op.cit.,hlm. 516.

35 Ibid., hlm. 440.

$36 \quad$ Ibid., hlm. 477.
والقياس من وجهين: أحدهما أن يكون الشئ في معنى الأصل فلا يختلف القياس فه وأن يكون الشئ له في الأصول أشباه. فذالك يلحق بأولاها به

$$
\text { وأكثرها شبها فيه. وقد يختلف القاسيون في هذا . } 37
$$

Qiyas dapat dilihat dari dua bentuk: Pertama, masalab (kasus) yang dipersoalkan sudah tercakup di dalam pengertian ashal (ketentuan pokok). Qiyas dalam bentuk ini tidak ada perbedaan pendapat (di kalangan para abli). Kedua, masalah (kasus) yang dipersoalkan memiliki kemiripan dengan beberapa makna yang ada pada beberapa ashal (ketentuan pokok). Dalam hal ini qiyas diterapkan kepada ashal yang paling utama dan lebih banyak kemiripannya. Qiyas bentuk kedua ini banyak menimbulkan perbedaan pendapat di kalangan pelaku qiyas.

... فالإ جتهاد أبدا لا يكون إلا على طلب شئ وطلب الشئ لا يكون إلا بالدلائل , والدلائل هي القياس. 38

Ijtihad selamanya tidak boleh dilakukan kecuali untuk mencari (bukum) suatu kasus dan mencari (bukum) suatu kasus tidak akan dapat dilakukan tanpa dalildalil. Dalil-dalil itu adalah qiyas.

Dari beberapa ungkapan di atas dapat dilihat gambaran bagaimana konsep qiyas yang dimaksud oleh Imam Syafi'i. Apabila dirumuskan dalam satu definisi dapat dikatakan bahwa qiyas adalah pengambilan hukum atas suatu kejadian atau peristiwa yang tidak terdapat nas kongkret yang menetapkan hukum atas peristiwa tersebut, dengan mengambil makna yang tersirat dari suatu nas karena adanya kesamaan makna (illat) yang terkandung di dalam nas itu dengan makna (illat) yang terdapat di dalam peristiwa atau kasus tersebut.

Mengenai bentuk-bentuk qiyas, menurut Imam Syafi i, ada tiga: Pertama, qiyas aqwa (qiyas yang lebih kuat). Kedua, qiyas musawi (qiyas yang sama). Ketiga, qiyas adl'af (qiyas yang lebih lemah). 39

Adapun yang dimaksud dengan al-qiyas alaqwa ialah al-furu' (cabang) lebih utama penetapan hukumnya daripada al-ashl (pokok). Al-qiyas almusawi ialah qiyas yang al-furu' menempati posisi yang sama dengan al-ashl. Qiyas ini disebut juga qiyas fi ma'na al-ashl, qiyas jaly, atau qiyas bi nafy alfariq. Sedangkan al-qiyas al-adl'af ialah qiyas yang

37 Ibid., hlm. 479

38 Ibid., hlm. 505

39 Ahmad Nahrawi Abd as-Salam, Al-Imam Asy-Syafi'iy fi Madzahibaih al-Qadim wa al-Jadid, Maktabah AsySyabab, Kairo, 1988, hlm. 395. 
al-furu' lebih lemah atau lebih rendah illat hukumnya dari pada al-ashl.40

Dari uraian itu pula terlihat gambaran bahwa suatu maslahat yang tidak bisa dicarikan rujukannya dari nas tidak bisa dimasukkan ke dalam qiyas menurut konsep Imam Syafi'i. Ia sendiri tidak bisa menerima bentuk maslahat semacam itu. Baginya, sesuatu yang tidak ada dasar nasnya sama sekali, baik eksplisit maupun implisit, tidak bisa dijadikan sebagai dalil syara'. Alasan inilah yang menyebabkan ia secara tegas menolak kehujjahan istihsan karena istibsan dianggapnya sebagai suatu teori istinbat yang menetapkan hukum bukan berdasarkan nas tetapi berdasarkan keinginan pelakunya semata dan mencari yang enaknya saja. Ia mengatakan:

$$
\text { الإستحسان تلذذ وقول بالهوى } 41
$$

Istibsan adalah berenak-enakan dan perkataan yang diliputi bawa nafsu

Karena dasar dari qiyas adalah nas maka nas menempati posisi yang penting dan kedudukannya lebih tinggi daripada qiyas. Oleh sebab itu, di dalam tertib sumber hukum Imam Syafi'i qiyas menempati urutan keempat setelah Al-Quran, Sunnah, dan ijma'.

Sebagai konsekuensi dari posisi ini, selama masih ada nas Kitab Allah, Sunnah Rasul, atau ijma' selama itu pula qiyas tidak digunakan. Dapat dikatakan, qiyas merupakan "pintu darurat" disaat nas kongkret tidak ada. Konsekuensi lain adalah qiyas tidak boleh bertentangan dengan nas. Apa pun bentuknya, qiyas yang bertentangan dengan nas adalah batal.

Apabila al-mashlahah al-mursalah termasuk di dalam konsep qiyas Imam Syafi'i berarti dapat dikatakan bahwa sebenarnya Imam Syafi'i juga menggunakan al-mashlabah al-mursalab di dalam teori istinbat hukumnya. Hal ini diakui oleh para ulama yang telah mempelajari konsep Imam Syafi'i tentang qiyas. Menurut mereka, Imam Syafi'i tidak memasukkan al-mashlabah al-mursalab secara eksplisit di dalam urutan dalil-dalil hukumnya bukan berarti ia menolak, tetapi karena ia memandang al-mashlahah al-mursalab itu bukan merupakan dalil hukum yang berdiri sendiri. ${ }^{42}$

40 Lihat Ibid., hlm. 395-398.

41 Dr. `Abd alKarim Zaidan, op. cit., hlm. 234.

42 Dr. H. Sulaiman Abdullah, Dinamika Qiyas Dalam Pembaharuan Hukum Islam: Kajian Konsep Qiyas Imam Syafi i, Pedoman Ilmu Jaya, Jakarta, cet. pertama, 1996, hlm. 178.
Satu hal yang perlu ditegaskan di sini ialah bahwa masuknya al-mashlahah al-mursalah ke dalam qiyas Imam Syafi'i sebagaimana diuraikan di atas karena pengertian al-mashlahah al-mursalah tersebut tidak lain kecuali al-mashlahab almula'imah li jins tasharrufat asy-Syari' atau yang sering disebut secara singkat dengan al-mashlahah al-mula'imah. Pengertian semacam ini pulalah yang dipegang oleh Imam Malik sebagai pembawa bendera al-mashlahah al-mursalah di dalam dunia ushul Fiqih.

Adapun al-mashlabah al-mursalab dalam pengertian jins maslahatnya tidak ada sama sekali rujukannya kepada nas sehingga tidak sejalan dengan apa yang dimaksud dengan al-mashlahah al-mula'imah tentu ditolak oleh Imam Syafi'i. Maslahat semacam ini tidak bisa dimasukkan ke dalam qiyas yang dikonsepsikannya. Kalangan Syafi'iyah terkadang menyebutnya dengan nama al-mashlabah al-gharibah dan posisinya di kalangan mereka sama dengan istih san.

Hal ini perlu ditegaskan karena di dalam beberapa kitab karya para pengikut Imam Syafi'i sering juga dijumpai istilah al-mashlahah almursalah yang dinyatakan ditolak oleh mereka. Penolakan tersebut terjadi karena pengertian almashlahah al-mursalah yang dimaksudkan mereka tidak lain kecuali al-mashlahah al-gharibab bukan almashlahah al-mula'imah.

\section{Kesimpulan}

1. Konsep qiyas Imam Syafi'i memiliki jangkauan yang sangat luas sebagai alternatif pemecahan peroblema hukum pada peristiwa-peristiwa yang tidak terdapat ketentuan hukumnya secara eksplisit di dalam nas, baik Al-Quran maupun hadis. Dengan keluasan konsep qiyas tersebut berbagai kasus atau peristiwa yang dihadapi oleh umat manusia dapat dicarikan jalan keluarnya sehingga tidak ada masalah yang tidak bisa diselesaikan dan tidak akan terjadi kevakuman hukum.

2. Imam Syafi'i tidak membicarakan masalah almashlahah al-mursalab di dalam teori istinbatnya tetapi masalah tersebut sudah termasuk di dalam konsep qiyas yang dikemukakannya. Hal ini disebabkan karena di dalam almashlahab al-mursalah terkandung jenis illat yang sama dengan illat yang terkandung di dalam peristiwa yang sudah ada ketentuan hukumnya di dalam nas.

3. Al-mashlabah al-mursalah yang termasuk di dalam konsep qiyas Imam Syafi'i ini adalah almashlahah al-mula imah li jins tasharrufat asy- 
Syari' sebagaimana yang dimaksudkan oleh Imam Malik bin Anas, pelopor dan pembawa konsep al-mashlabah al-mursalah.

4. Adanya sebagian golongan Syafi'iyah yang menolak kehujahan al-mashlahah al-mursalah sebagaimana tergambar di dalam beberapa kitab karya mereka bukanlah berarti bertentangan dengan Imam Syafi'i tetapi karena pengertian mereka tentang al-mashlabah al-mursalab tidak persis sama dengan pengertian sebagaimana dikemukakan di atas. Al-mashlahah al-mursalah yang ditolak mereka pada dasarnya adalah al-mashlabah al-mursalab dalam pengertian al-mashlabah al-gharibah bukan dalam pengertian al-mashlahab almula imah.

5. Persentuhan al-mashlahah al-mursalah di dalam konsep qiyas Imam Syafi'i terletak pada adanya kesamaan jins yang terkandung di dalam furu' pada kasus al-mashlahah al-mursalah dengan jins yang terkandung di dalam ashl. Hal ini sejalan dengan hakekat dari qiyas itu sendiri. Di samping itu, qiyas harus didasarkan kepada nas dan nas selalu mengacu kepada maqashid asy-syari'ab yang intinya adalah al-mashlabah. Dengan demikian, aspek al-mashlabah merupakan bagian penting yang tidak bisa dipisahkan di dalam penerapan qiyas.

\section{Daftar Rujukan:}

Abdullah, Sulaiman, Dinamika Qiyas Dalam Pembaharuan Hukum Islam: Kajian Konsep Qiyas Imam Syafi i, Pedoman Ilmu Jaya, Jakarta, cet. pertama, 1996.

Al-Ghazali, Abu Hamid Muhammad bin Muhammad, Al-Mustashfa min Tlm alUshul, Dar al-Fikr, Kairo, 1937.

Syifa' al-Ghalil fì Bayan asy-Syabh alMubil wa Masalike at-Ta 'Vil, Maktabah AlAzhar, Kairo, t.th.
Al-Khin, Mushthafa Sa'id, Asar al-Ikbtilaf fi alQawa'id al-Ushuliyyah fi al-Ikbtilaf alFuqaha, Mu'assasah ar-Risalah, Beirut, 1972.

Ar-Razi, Fakhruddin, Al-Mabshul fi ' Ilm Usbul alFiqh, Jilid II, Jami`al-Imam Muhammad bin Sa ud, Mekkah,1980.

As-Salam, Ahmad Nahrawi Abd, Al-Imam AsySyafi'iy fi Madzabibaih al-Qadim wa al-Jadid, Maktabah Asy-Syabab, Kairo, 1988.

Asy-Syafi'i, Muhammad bin Idris, Ar-Risalah, Tahqiq Ahmad Muhammad Syakir, Dar at-Turats, Kairo, cet. ke-2, 1979. , Al-Umm, Dar al-Fikr, Beirut, cet. II, 1983.

Asy-Syathibi, Abu Ishaq, Al-Muwafaqat fi Ushul asy-Syari'ah, tahqiq Syekh Abdullah Darraz, Juz II, Dar al-Kutub al-'Ilmiyah, Beirut, cet. pertama, 1991.

Dewan Penterjemah, Al-Quran dan Terjemabnya, Mujamma' Khadim al-Haramain asySyarifain al-Malik Fahd li Thiba at alMushhaf asy-Syarif, Saudi Arabia, t.th.

Hassan, Husain Hamid, Nazhariyyah al-Mashlabah fi al-Fiqh al-Islamiy, Dar an-Nahdhah al'Arabiyyah, Kairo, 1971.

Khallaf, 'Abd al-Wahhab, Tlm Ushul al-Figh, Dar al-Qalam, Kuwait, Cet. ke-12, 1978.

Usman, Mukhlis, Kaidah-Kaidah Ushuliyah dan Fiqhiyah, PT Raja Grafindo Persada, Jakarta, cet. II, 1997.

Yahya, Mukhtar dan Fatchurrahman, Dasar-Dasar Pembinaan Hukum Fiqh Islami, PT AlMa rif, Bandung, 1986.

Zaidan, `Abd al-Karim, Al-Wajiz fi Ushul al-Fiqh, Muassasah ar-Risalah, Beirut, cet. ke-7, 1998.

Zahrah, Muhammad Abu, Ushul al-Fiqih, Dar alFikr al-'Arabi, Kairo, t.th. 